\title{
COMPARISON OF OCEANIC $\Delta^{14}$ C DATA WITH THOSE OF GEOSECS: VERTICAL PROFILES IN 1973 (GEOSECS) AND IN 1980 AT $\left(30^{\circ} \mathrm{N}, 170^{\circ}\right.$ E) IN THE NORTHWESTERN PACIFIC OCEAN
}

\author{
TOSHITAKA GAMO, YOSHIO HORIBE *
}

Ocean Research Institute, University of Tokyo, Minamidai, Nakano-ku Tokyo 164, Japan

and

\section{HIROMI KOBAYASHI}

C-14 Dating Laboratory, Faculty of Science, University of Tokyo, Hongo Bunkyo-ku, Tokyo 113, Japan

ABSTRACT. The vertical profile of radiocarbon at $\left(30^{\circ} \mathrm{N}, 170^{\circ} \mathrm{E}\right)$ measured in 1980 was compared with the GEOSECS data measured in $1973 .{ }^{14} \mathrm{C}$ was extracted from $200 \mathrm{~L}$ of sea water, converted to $\mathrm{C}_{2} \mathrm{H}_{2}$, and analyzed with a gas proportional counter. Our profile and that of GEOSECS were in good agreement below $700 \mathrm{~m}$ depth without systematic deviation of $\Delta^{14} \mathrm{C}$. values between both measurements. On the other hand, a $\Delta^{14} \mathrm{C}$ increase was observed above $700 \mathrm{~m}$ depth, reflecting the transient addition, in 6.6 years, of bomb ${ }^{14} \mathrm{C}$ to the intermediate layer from the atmosphere.

\section{INTRODUCTION}

It is well known that ${ }^{14} \mathrm{C}$ is one of the most important geochemical tracers for studying ocean circulation and mixing processes (eg, Broecker \& Peng, 1982). The ${ }^{14} \mathrm{C}$ distributions in the Pacific Ocean were obtained in detail during the GEOSECS operation in 1973-1974 (Östlund \& Stuiver, $1980)$. We re-occupied one of the GEOSECS stations-Station 226 $(30)^{\circ} \mathrm{N}, 170^{\circ} \mathrm{E}$ )-during the CYGNUS Expedition (KH-80-2) of $R$ V Hakuho Maru in 1980 (Horibe, 1983), in order to compare our $\Delta^{14} \mathrm{C}$ data with those of the GEOSECS group. This paper reports the method for $\Delta^{14} \mathrm{C}$ measurement and the result of intercomparison of the $\Delta^{14} \mathrm{C}$ profiles.

\section{EXPERIMENTAL}

Fifteen seawater samples from surface to bottom (as listed in Table 1) were collected by using water-tight PVC 230L water samplers (Horibe, $1981)$ at Station CYGNUS $11\left(30^{\circ} 32^{\prime} \mathrm{N}, 170^{\circ} 39^{\prime} \mathrm{E}\right)$. To measure the precise depth and temperature of each sample, a sonar pinger (Benthos, Model 2216) and reversing thermometers were attached to the sampler.

As soon as the sampler was brought on deck, 200L of sea water were transferred into a stainless steel barrel to extract the dissolved total inorganic carbon $\left(\mathrm{SCO}_{2}\right)$. The extraction method was similar to that reported by Östlund, Dorsey and Rooth (1974). The sea water was acidified with HCl and stripped of $\mathrm{\Sigma CO}_{2}$ by circulating $\mathrm{CO}_{2}$-free nitrogen carrier gas. The extracted $\mathrm{CO}_{2}$ was absorbed in $800 \mathrm{ml}$ carbonate-free $4 \mathrm{~N} \mathrm{NaOH}$ solution which was prepared by diluting clear saturated solution of $\mathrm{NaOH}$ with distilled water just before its use. The flow rate of the carrier gas was

* Present address: Isotope Laboratory, Scripps Institution of Oceanography, University of California, La Jolla 92093 
TABLE 1

Results of measurements at Station CYGNUS $11\left(30^{\circ} 32^{\prime} \mathrm{N}, 170^{\circ} 39^{\prime} \mathrm{E}\right)$ June 6-7, 1980

\begin{tabular}{cccrr}
\hline $\begin{array}{c}\text { Sample } \\
\text { no. }\end{array}$ & $\begin{array}{c}\text { Depth } \\
(\mathrm{m})\end{array}$ & \multicolumn{1}{c}{$\begin{array}{c}\mathrm{A}_{\mathrm{SN}} \\
(\mathrm{cpm})\end{array}$} & $\begin{array}{c}\delta^{13} \mathrm{C} \\
(\% 0)\end{array}$ & $\begin{array}{c}\Delta^{14} \mathrm{C} \\
(\% 0)\end{array}$ \\
\hline TK-376 & 10 & $15.41 \pm 0.06$ & 1.0 & $164 \pm 5$ \\
TK-375 & 94 & $14.90 \pm 0.06$ & 0.7 & $126 \pm 5$ \\
TK-374 & 221 & $14.75 \pm 0.05$ & 0.3 & $116 \pm 5$ \\
TK-373 & 467 & $13.43 \pm 0.06$ & -0.4 & $17 \pm 5$ \\
TK-372 & 684 & $11.95 \pm 0.05$ & -1.0 & $-94 \pm 4$ \\
TK-371 & 808 & $10.92 \pm 0.05$ & -1.4 & $-171 \pm 4$ \\
TK-370 & 1001 & $10.71 \pm 0.05$ & -1.7 & $-186 \pm 4$ \\
TK-369 & 1235 & $10.23 \pm 0.05$ & -1.8 & $-223 \pm 4$ \\
TK-368 & 1559 & $10.10 \pm 0.04$ & -1.7 & $-233 \pm 4$ \\
TK-367 & 2022 & $10.02 \pm 0.05$ & -0.1 & $-240 \pm 4$ \\
TK-366 & 2542 & $10.02 \pm 0.05$ & -0.5 & $-222 \pm 4$ \\
TK-365 & 3012 & $10.27 \pm 0.05$ & -0.6 & $-219 \pm 4$ \\
TK-364 & 4055 & $10.31 \pm 0.05$ & -0.9 & $-217 \pm 4$ \\
TK-363 & 4953 & $10.33 \pm 0.05$ & -1.0 & $-206 \pm 4$ \\
TK-362 & 5396 & $10.47 \pm 0.04$ & \\
\hline
\end{tabular}

adjusted to ca $6 \mathrm{~L}$ per minute. By analyzing the remaining $\Sigma \mathrm{CO}_{2}$ content in the sample sea water with the gas chromatograph (Gamo \& Horibe, 1980) at appropriate time intervals during the extraction, it was found that 3 hours were necessary to achieve $95 \%$ extraction of $\Sigma \mathrm{CO}_{2}$. In this study, the extraction was continued for $>4$ hours for every sample.

In the laboratory on land, $\mathrm{CO}_{2}$ was recovered by acidifying the $\mathrm{NaOH}$ solution with $\mathrm{HC1}$, and converted to $\mathrm{C}_{2} \mathrm{H}_{2}$ gas for $\beta$ counting. Standard gases were prepared from the old NBS oxalic acid by using a wet oxidation method. The ${ }^{14} \mathrm{C}$ measurement was carried out with the gas proportional counter described by Kobayashi et al (1974).

A fraction of the $\mathrm{C}_{2} \mathrm{H}_{2}$ gas was subjected to quantitative combustion to $\mathrm{CO}_{2}$, and its $\delta^{13} \mathrm{C}$ relative to PDB was measured with the Finnigan MAT 250 mass spectrometer. The $\Delta^{14} \mathrm{C}$ value of the sample was calculated according to the following equation:

$$
\Delta^{14} \mathrm{C}=\left(\mathrm{A}_{\mathrm{SN}} / \mathrm{A}_{\mathrm{ABS}}-1\right) \times 1000(\%)
$$

where $\mathrm{A}_{\mathrm{SN}}$ is the net ${ }^{14} \mathrm{C}$ activity of the sample normalized to $\delta^{13} \mathrm{C}=-25 \%$, and $\mathrm{A}_{\mathrm{ABS}}$ (absolute international standard activity) is $95 \%$ of the net oxalic acid activity in $\mathrm{AD} 1950$ which is normalized to $\delta^{13} \mathrm{C}=-19 \%$ (Stuiver \& Polach, 1977).

The standard deviation for each $\Delta^{14} \mathrm{C}$ data was calculated from statistical error of $\beta$ countings. When the total count is $N$ (counts), its standard deviation is $\sqrt{\mathrm{N}}$. The counting rate is expressed as N/T (T: counting time) and its standard deviation is $\sqrt{\mathrm{N} / \mathrm{T}^{2}}$. After the standard deviations for $\mathrm{A}_{\mathrm{SN}}$ and $\mathrm{A}_{\mathrm{ABs}}$ are obtained as $\sigma_{1}$ and $\sigma_{2}$, respectively, that for $\Delta^{14} \mathrm{C}$ is calculated by the following equation.

$$
\sigma=\left(\frac{1}{\mathrm{~A}_{\mathrm{ABS}}{ }^{2}} \sqrt{\left(\mathrm{A}_{\mathrm{ABS}} \cdot \sigma_{1}\right)^{2}+\left(\mathrm{A}_{\mathrm{SN}} \cdot \sigma_{2}\right)^{2}}\right) \times 1000
$$


TABLE 2

Results of the NBS standard measurements

\begin{tabular}{rccc}
\hline NBS no. & $\begin{array}{c}\mathrm{A}_{\mathrm{ox}} \\
(\mathrm{cpm})\end{array}$ & $\begin{array}{c}\delta^{13} \mathrm{C} \\
(\%)\end{array}$ & $\begin{array}{c}\mathrm{A}_{\mathrm{ABS}} \\
(\mathrm{cpm})\end{array}$ \\
\hline NBS-42 & $13.02 \pm 0.06$ & -22.9 & $12.51 \pm 0.06$ \\
-42 & $13.08 \pm 0.07$ & -22.9 & $12.57 \pm 0.07$ \\
-43 & $13.14 \pm 0.05$ & -20.9 & $12.58 \pm 0.05$ \\
\hline
\end{tabular}

\section{RESULTS AND DISCUSSION}

Two standard gases (NBS-42 and NBS-43) were prepared for this study. Table 2 shows the results of the standard gas measurements: their net activity $\left(\mathrm{A}_{\mathrm{OX}}\right), \delta^{13} \mathrm{C}$, and $\mathrm{A}_{\mathrm{ABS}}$. The standard gases were measured three times at intervals in the course of successive sample measurements. The good reproducibility of the value of $\mathrm{A}_{\mathrm{ABS}}$ (average value: $12.55 \pm 0.03 \mathrm{cpm}$ ) reflected the stability of the counting system throughout the study.

The results of sample measurements and calculated $\Delta^{14} \mathrm{C}$ values were listed in Table 1. Figure 1 is the vertical $\Delta^{14} \mathrm{C}$ profile at CYGNUS Station 11 together with that at GEOSECS Station 226 (Ostlund \& Stuiver, 1980). The former samples were collected June 6-7, 1980, and the latter November 9 , 1973. In deep waters below $700 \mathrm{~m}$ depth, both profiles are in good agreement with each other within the analytical error as indicated by a solid line

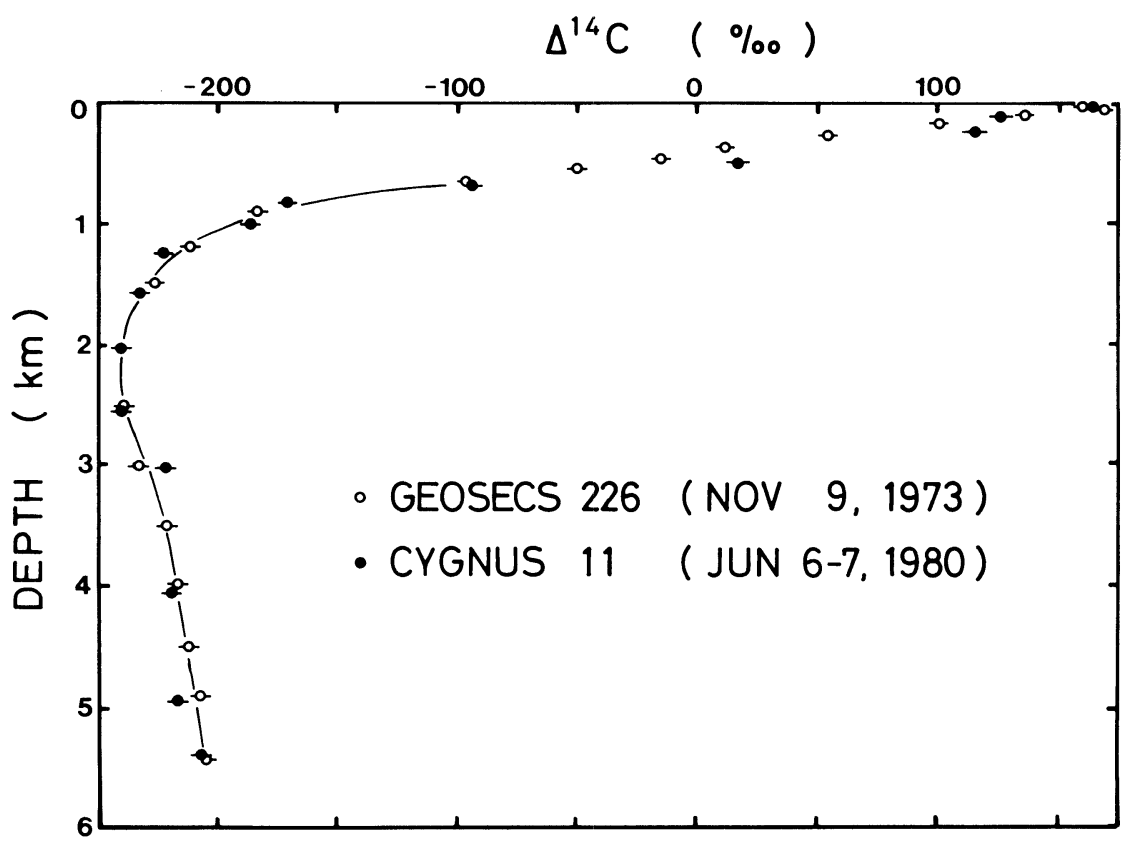

Fig 1. Comparison of the vertical profiles of $\Delta^{14} \mathrm{C}$ between GEOSECS $226\left(30^{\circ} 34^{\prime} \mathrm{N}\right.$ $170^{\circ} 38^{\prime} \mathrm{E}$ ) in 1973 and CYGNUS $11\left(30^{\circ} 32^{\prime} \mathrm{N}, 170^{\circ} 39^{\prime} \mathrm{E}\right)$ in 1980 . The solid line was arbitrarily drawn to show good agreement between both profiles below $700 \mathrm{~m}$ depth. 
in Figure 1. Thus, there is no systematic deviation between our $\Delta^{14} \mathrm{C}$ measurements and those of the GEOSECS group.

As shown in Figure 1, above $700 \mathrm{~m}$ depth our $1980 \Delta^{14} \mathrm{C}$ data at $221 \mathrm{~m}$ and $467 \mathrm{~m}$ depths are significantly greater than the 1973 GEOSECS values interpolated at the same depths. Since it was shown above that there is no analytical bias between both measurements, the increase of $\Delta^{14} \mathrm{C}$ is real, possibly reflecting the addition of bomb ${ }^{14} \mathrm{C}$ from the atmosphere. As the $\Delta^{14} \mathrm{C}$ increase was limited in the intermediate depth range and no change was observed in the surface water, it is supposed that the bomb ${ }^{14} \mathrm{C}$ was supplied to the intermediate water by transport of sinking surface sea water in the northern region of the Pacific.

The similar increase of $\Delta^{14} \mathrm{C}$ in the intermediate layer compared with the GEOSECS data was observed also at $\left(25^{\circ} \mathrm{N}, 170^{\circ} \mathrm{E}\right)$ (GEOSECS 227, CEPHEUS 5) and at $\left(12^{\circ} 45^{\prime} \mathrm{N}, 173^{\circ} 14^{\prime} \mathrm{E}\right)$ (GEOSECS 229, CEPHEUS 8) during the CEPHEUS Expedition of $R V$ Hakuho Maru in 1982 as presented by Horibe and Gamo (1983). The transient behavior of ${ }^{14} \mathrm{C}$ in the intermediate layer and its oceanographic meanings will be discussed elsewhere in detail together with other results so far obtained in the northwestern Pacific Ocean.

\section{ACKNOWLEDGMENTS}

The authors thank M Ishiguchi and $\mathrm{M}$ Koizumi for ${ }^{14} \mathrm{C}$ measurements. Thanks are also due the officers and crew of $R V$ Hakuho Maru for their help in large-volume water sampling. This work was supported by grantsin-aid (Nos. 57540321, 56117009, 57110008, and 58102009) from the Ministry of Education, Culture and Science to the University of Tokyo.

REFERENCES

Broecker, W S and Peng, T -H, 1982, Tracers in the sea: New York, Eldigio Press, 690 p.

Gamo, T and Horibe, Y, 1980, Precise determination of dissolved gases in sea water by shipboard gas chromatography: Bull Chem Soc Japan, v 53, p 2839-2842.

Horibe, Y, 1981, Preliminary report of the Hakuho Maru Cruise KH-77-3 (Pegasus Expedition): Ocean Research Inst, Univ Tokyo, 55 p.

1983, Preliminary report of the Hakuho Maru Cruise KH-80-2 (CYGNUS Expedition) and the Hakuho Maru Cruise KH-82-1 (CEPHEUS Expedition): Ocean Research Inst, Univ Tokyo, $78 \mathrm{p}$.

Horibe, $\mathrm{Y}$ and Gamo, T, 1983, Tracer studies on the transport of carbon dioxide into the ocean in the central North Pacific (abs): IUGG General Assembly, 18th, Hamburg.

Kobayashi, H, Hirose, T, Sugino, M and Watanabe, N, 1974, University of Tokyo radiocarbon measurements V: Radiocarbon, v 16, no. 3, p 381-387.

Östlund, H G, Dorsey, H G, and Rooth, C G, 1974, GEOSECS North Atlantic radiocarbon and tritium results: Earth Planetary Sci Letters, v 23, p 69-86.

Östlund, H G and Stuiver, M, 1980, GEOSECS Pacific radiocarbon: Radiocarbon, v 22, no. 1, p 25-53.

Stuiver, M and Polach, H A, 1977, Discussion: Reporting of ${ }^{14} \mathrm{C}$ data: Radiocarbon, v 19, no. 3 , p 355-363. 